\title{
Literary words of foreign origin as social markers in Jeffrey Archer's novels
}

\author{
Tatiana A. IVUSHKINA \\ MGIMO University \\ Moscow, Russia
}

\begin{abstract}
The paper is aimed at studying the use of literary words of foreign origin in modern fiction from a sociolinguistic point of view, which presupposes establishing a correlation between this category of words in a speech portrayal or narrative and a social status of the speaker, and verifying that they serve as indices of socially privileged identity in British literature of the $X X 1^{\text {st }}$ century. This research is the continuation of the diachronic sociolinguistic study of the upper-class speech portrayals which has traced the distinctive features in their speech and has revealed that literary words of foreign origin unambiguously testify to the social position of a character/speaker and serve as social indices. The question arises then whether it holds true for modern upper-class speakers/speech portrayals, given all the transformations a new millennium has brought about. To this end we have selected 60 contexts from two novels by Jeffrey Archer - Not a Penny More, Not a Penny Less (2004) and A Prisoner of Birth (2008), and subjected them to a careful examination. A graduate from Oxford and representative of socially privileged classes, Archer gives a wide depiction of characters with different social backgrounds and statuses. The analysis of the novels based on the contextual and functional approaches to the study enabled us to categorize the selected words into four relevant groups. The first class represented by terms (commodity, debenture, assets, luminescence, etc.) serves to unambiguously indicate education, occupation, and fields of knowledge or communicative situations in which a character is involved. The second class is formed of words used in conjunction with their Germanic counterparts (perspiration - sweat, padre - priest, convivial - friendly) to contrast the social position of the characters: literary words serving as social indices of upper class speakers, whereas their synonyms of Germanic origin characterize middle or lower class speech portrayals. The third class of words comprises socially marked words (verbs, nouns and adjectives), or U-words (the term first coined by Allan Ross and Nancy Mitford), the status acquired in the course of social history development (elegant, excellent, sophistication, authoritative, preposterous, etc.). The fourth class includes words used in a humorous or ironic meaning to convey the narrator's attitude to the characters or the situation itself (ministrations, histrionic, etc.). Words of this group are perceived as stylistic "aliens", as they create incongruity between style and subject matter. The social implication of the selected words is enhanced by French words and phrases often accompanying them.
\end{abstract}

Keywords: literary words of foreign origin, social context, social index, identity, socially privileged classes, categories of words

\section{For citation:}

Ivushkina, Tatiana A. 2020. Literary words of foreign origin as social markers in Jeffrey Archer's novels. Russian Journal of Linguistics 24 (4). 816-830. DOI: 10.22363/2687-00882020-24-4-816-830 
Научная статья

\title{
Литературные заимствования как социальные маркеры в романах Джеффри Арчера
}

\section{Т.А. ИВУШКИНА}

\author{
Московский государственный институт международных отношений \\ (университет) МИД России \\ Москва, Россия
}

\begin{abstract}
Аннотация
В данной статье рассматриваются литературные заимствования в речи персонажей современной английской литературы с целью установления их статуса слов, используемых для социальной идентификации представителей высших классов общества. Актуальность исследования обусловлена неослабевающим интересом к социальным различиям в языке и отсутствием социолингвистического изучения данной категории слов на материале современной английской литературы. Проведенный нами ранее диахронический анализ речи представителей высших классов Великобритании на материале художественных произведений XIX-XX вв., выявивший корреляцию между литературными заимствованиями в речи героев и высоким социальным статусом последних, ставит вопрос о релевантности данной взаимосвязи в XXI в. глобальных изменений. Материалом исследования послужили два романа Джеффри Арчера Not a Penny More, Not a Penny Less (2004) и A Prisoner of Birth (2008), из которых выбраны 60 контекстов. Анализ романов позволил выделить четыре группы слов: первая представлена терминами (commodity, debenture, assets, luminescence, etc.), однозначно указывающими на образованность персонажей, их род занятий, а также на ситуацию общения, в которую попадают герои произведений; вторая группа включает в себя литературные слова, используемые в паре с синонимичным словом германского происхождения (perspiration sweat, padre - priest, convivial - friendly) для создания социального контраста: социальной привилегированности и принадлежности персонажей к средним и низшим классам соответственно; третья группа - это U-words, социально-маркированные слова представителей высших классов общества (elegant, excellent, sophistication, authoritative, preposterous, etc.); четвертая группа образуется литературными словами с иронической или юмористической коннотациями (ministrations, histrionic, etc.), а также создающими намеренный контраст между стилем высказывания и предметом речи, часто усиливаемый французскими словами. Проведенное исследование подтвердило, что литературные заимствования выступают в художественном произведении социальными индексами и несут с собой имплицитную информацию, которая отличается степенью сложности ее инферентного вывода: от простой (термины) к более сложной (словарь высших классов общества), требующей от читателя специальных знаний. Результаты исследования способствуют более глубокому изучению заложенного в данной категории слов потенциала социальной идентификации как в тексте художественного произведения, так и живой речи. Исследование литературных заимствований на материале художественной литературы других авторов может пополнить выделенную типологию.
\end{abstract}

Ключевые слова: литературные заимствования, социальный индекс, идентификация, привилегированные классы, категоризаџия, коннотаџия, контекст

\section{Для цитирования:}

Ivushkina T.A. Literary words of foreign origin as social markers in Jeffrey Archer's novels. Russian Journal of Linguistics. 2020. Vol. 24. № 4. P. 816-830. DOI: 10.22363/2687-00882020-24-4-816-830 


\section{Introduction}

On the face of it, literary words are self-explanatory: they explicitly refer to a literary style connected with literary traditions, writing and, consequently, education. They became part of English culture and language historically, as the result of conquests (the Norman conquest being the longest of them) and the influence of Latin, French and Greek, which immensely contributed to the development not only of English literature (the first literary works were translations from these languages) but scientific and society language as well. The first literary translation experiments preceded Jeffrey Chaucer's recognition as the national founder of the English language and literature. No wonder, there is still a significant stratum of assimilated foreign words which juxtaposes the stratum of colloquial words against the background of a stylistically neutral layer of lexis. Both literary and colloquial words bear connotations opposite in their nature: loftiness, elevation, poeticism and archaism, solemnity and grandiloquence associated with literary words, and informality, intimacy and friendliness associated with colloquial ones (Crystal 2010: 38-45).

This paper focuses on literary words used in modern English fiction. As is known, this layer of English vocabulary is not homogeneous: it comprises terms, archaic words and poetic words, historicisms, barbarisms and neologisms. Linguists from different countries give different classifications and categorization of the words constituting the literary stratum of the English vocabulary (Kuznets 1960, Kostomarov 1965, Fowler 1966, Quirk 1972a, 1972b, Gak 1977, Algeo 1980, Carter, Nash 1983, 1991, Craig 1986, Morokhovsky 1991, Skrebnev 2003, Jarceva 2004, Renouf 2004, Antrushina 2006, Akhmanova 2009, Galperin 2012, Arnold 2016, Rakushina, Ivushkina 2018, Rakushina 2019, et al.) as well as literature and discourse (Aitchinson 1987, Cook 1994). Central to this research are the words of foreign origin, primarily French, Greek and Latin, which successfully assimilated into the English language and are often not perceived as loan words. This category of words has been revealed to be part and parcel of upper class portrayals in the English literature (Ivushkina 2012, 2017).

\section{Methodology And Material}

The paper is aimed at studying the use of literary words of foreign origin from a sociolinguistic point of view, which presupposes establishing correlations between linguistic and social forms of characterization, verifying social implications of literary words in modern fiction speech representation. In our previous papers, the findings suggested that it is largely socially privileged classes of society that resort to this category of words, hence our scholarly interest in how it functions now and whether it retains its social indexicality. It is noteworthy that the very classification of literary words into different groups (terms, archaic, poetic, obsolete, etc.) basically gives little for the research, as historically, words (all words and literary words among others) tend to evolve, shifting their stylistic connotations, expanding or narrowing their semantics, becoming obsolete or 
coming into use again with new meanings. What really matters for our sociolinguistic research are social contexts and functions they perform. It would not be surprising to hear a lot of literary words in a scholarly lecture or presentation at a university, we take it for granted. When it comes to everyday situations, communication with friends and colleagues, with acquaintances or strangers, this is where we feel either social equality/inequality or distance. This inference was reinforced with a series of interviews with British linguists who gave comments on the usage of a number of literary words frequent in speech portrayals of the British literature. The fact that foreign speakers of English are always like on a minefield with literary words under analysis, adds to the realization that in order to use this category of words appropriately, one should acquire solid knowledge of foreign languages taught at classical universities and be part of social culture. These considerations determined the approaches to the study - sociolinguistic (in social contexts) and functional (the performance). We have selected 60 contexts in order to subject the contextual use of lexical units to a careful examination. It was the selection of literary words of foreign origin in contexts that underlie the research. Empirically, we could not ignore the recurrence of some contexts with literary words under analysis which allowed us to classify them into four proposed groups (to be extended on the material of other authors). Our research is aimed at the analysis of those contexts and connotations of selected words and their social implications in the British literature and the way they are brought into play for this purpose. It should be noted that the narrator is considered as a character and studied on a par with speech portrayals.

Jeffrey Archer, one of the most bestselling British authors, has been chosen for analysis, firstly, as a graduate from Oxford University, an intrinsically upper class representative, part of upper class culture, and a bearer of socially marked upperclass language. The fact that Jeffrey Archer served for five years in the British House of Commons and 22 years in the House of Lords testifies to his invaluable experience in the upper echelons of society and his savoir faire. This is the reason why the narrator's speech has also been taken into consideration in our research on an equal footing with speech portrayals. Secondly, his novels depict characters belonging to different walks of life that allow us to draw a distinct line between the upper class representatives and those from middle or lower classes of the British society for contrasting socially marked linguistic differences. The study is carried out on two novels by Jeffrey Archer -Not a Penny More, Not a Penny Less (2004) and $A$ Prisoner of Birth (2008) in which the author presents characters of different social statuses. The total amount of pages is 921 .

\section{The Research and the Analysis}

The two novels served as a source of 60 contexts with literary words of foreign origin that drew our attention because they revealed similar patterns of social indexicality. The analysis of these contexts allowed us to categorize them into several classes. 


\section{a) CLASS 1}

The first group of words represents terms from different fields of knowledge, which reflect either the main characters' areas of activities or are used for their contrast or comparison. These words are of Latin or Greek origin, which is not surprising as these languages keep enriching the English language by generating new terms in order to designate emerging phenomena, inventions, objects and notions in different spheres of life. As the French linguist Antoinette Renouf specializing in the study of Gallicisms in English notes, "One purpose is to fill 'lacunae' or gaps in English, when there is no adequate word in English to convey a particular denotation or connotation, reference or nuance. Lacunae exist in English for French cultural concepts, inventions and institutions. ...Equally, if there is sometimes no single, neat word in English to express an English concept, and if the gap can be better filled in by a French word, we will adopt it" (Renouf 2004: 529).

the following words selected from the novels belong to this group:

- commodity (from a French word, from Latin commoditas): 1) a raw material or primary agricultural product that can be bought and sold, 2) a useful or valuable thing (LEXICO online): "Buy gold on my commodity account until it reaches $\$ 10$ million and then hold until you receive further instructions. Try and buy in the troughs and don't rush - be patient. Understood?" (Archer 2004: 1). The term 'commodity account' on the first page of the novel immediately immerses the reader into the world of commerce and trade, unfolding the dark side of doing business today which is based on criminal schemes and cheating, and holding the reader in suspense to the end of the novel.

- quarry from Old French quarriere based on Latin 'a square' (LEXICO):

Roger could not believe his luck. He did not even consult anyone at Sharpley \& Son, knowing only too well that they would try to talk him out of it. Harvey had counted on this and had assessed his quarry accurately (Archer 2004: 15). This term refers to oil and gas industry, the core of any economy, as it generates revenues like no other thus attracting unscrupulous people in the pursuit of profit.

- debenture from Latin debenture 'are owing' 'a long-term security yielding a fixed rate of interest, issued by a company and secured against assets' (LEXICO): "Can you join me at Wimbledon on Tuesday, June $25^{\text {th }}$ at 2 P.M., Centre Court, my usual debenture seat?" (Archer 2004: 2). The term reflects a banking sphere of activity, capital investment and property rights. It is part of a business world in which all the characters are unwillingly involved and thrown together in order to return their stolen money, as they say 'not a penny less, not a penny more'.

The following two terms reflect a different field of activity - medicine and the medicinal notions and conditions in which characters find themselves.

- prolapsed from Latin prolapse - 'slipped forward' (LEXICO): They christened her Rosalie, and she became the center of Harvey's attention, his only disappointment came when a prolapse closely followed by a hysterectomy prevented Arlene from bearing him any more children (Ibid., p. 19); and the term 
hysterectomy from Greek hustera 'womb' + -ectomy (LEXICO). Two terms only allow the reader to get into the family problem caused by Arlene's inability to give a birth to a child. The term recuperation from Latin recuperare (LEXICO) is from the same field used to denote recovery from illness, etc.

In the following example we find a term belonging to the sphere of physics luminescence which comes from Latin lumen (the emission of light by a substance that has not been heated, as in fluorescence or phosphorescence) (LEXICO): Later, Stephen had been more embarrassed than flattered by his appearance in the resulting piece written by Compton-Miller for The Times diary: academics are sparing with the word brilliant, but journalists are not. The more self-important of Stephen's Senior Common Room colleagues had not been amused to see him described as the brightest star in a firmament of moderate luminescence (Archer 2004: 73). The word 'firmament' is a literary word which came into English via French from Latin firmamentum, from firmare 'fix, settle' and means 'the sky, the heavens'. The combination of two lexical units translates the ironic attitude of the author towards journalist Compton-Miller, who 'was not sparing' with exaggerations.

The word baccarat of unknown origin came into the English language from French baccarat (LEXICO) and denotes a gambling card game: Jean-Pierre, at accost to Mr. Metcalfe of $\$ 25$ and a 48-hour wait, became an overseas member of The Claremont, London's most distinguished gaming club, and assessed his evenings watching the wealthy and lazy play baccarat and blackjack, their stakes often reaching \$1, 000 (Archer 2004: 116). In the novel it reflects the pastime of the rich and their involvement into playing dangerous games at large.

The word umpire from Old French nonper 'not equal' (LEXICO) in sports denotes an official who watches a game or match closely to enforce the rules and arbitrate on matters arising from the play: The little green scoreboards at the southern end of the court were flashing up the names of Kodeš and Stewart as the umpire took his seat on the high chair in the middle of the court directly overlooking the net (Archer 2004: 135).

The word assets, from Old French asez 'enough', based on Latin 'ad' (to) + satis 'enough' (LEXICO), an item of property owned by a person or company, regarded as having value and available to meet debts, commitments, or legacies reflects the world of business. In the novel used in singular it denotes a useful or valuable thing or person: Even Stephen was impressed by Jame's relaxed line of small talk, although he couldn't help recalling his academic results when at Christ Church and wondered whether the noble lord would in fact be an asset to his plans (Archer 2004: 84).

The adduced words of French, Latin or Greek origins are a few from a long list of those which function as terms unambiguously indicating spheres of their usage: medicine (prolapsed, hysterectomy, syringe, dentures, recuperation); finance (debenture, assets, value); law (verdict, judge, subpoena, convict, remand); physics (luminescence); gamble (baccarat); sports (umpire) and many others. In the article 
“Shall We Hors D'oeuvres?: The Assimilation of Gallicisms into English", Renouf writes, "According to our data, journalists in the Independent newspaper chiefly employ Gallicisms in the context of style, fashion, cuisine and licentiousness; also of relevant institutions (e.g. Channel Tunnel), matters of water and sea, as well as for the fairly predictable gamut of daily life and culture" (Renouf 2004: 530). It is relevant for the writers of fiction as well. These terms are initially aimed at showing the lifestyle of the characters and spheres of communication, the occupation of the characters and their social status as they reflect scientific notions and are supposed to be shared by the reader with education and erudition.

\section{b) CLASS 2}

The second group of words of foreign origin is composed of words (verbs, nouns and adjectives) of French or Latin origin, which have their synonymous Germanic counterparts in the English language. This group of words is of special interest as it reflects the historically grounded social division of words caused by the Norman invasion that had a colossal influence on the English vocabulary containing a long list of assimilated words in its record. Remaining dominant for more than three centuries, French has served as the language of the elite ruling classes of Great Britain, and having acquired socially marked implications of upper class language and culture, assimilated French and Latin words function as social and cultural indices in English fiction. The following examples demonstrate it:

(1) After a respectable period of time had passed, Henryk explained that he must return to work, thanked Mrs. Rennick for her cooperation, paid the bill and left. Outside on the street he whistled with relief. His new shirt was soaked in sweat (Mrs. Rennick would have called it perspiration), but he was out in the open and could breathe freely again (Archer 2004: 12).

Different social backgrounds of two characters - Henryk and Mrs. Rennick are drawn and highlighted by means of two synonymous nouns: "sweat" of Germanic origin and "perspiration" of French origin (from French perspire), the latter used in connection with an upper class representative. Henryk felt the social distance and therefore tension and uneasiness with Mrs. Rennick, who even made him sweat during their conversation; he got relieved only after he left her house. The use of the phrase 'whistled with relief' reinforces the difference between them as it obviously clashes with civility. The adjective 'respectable' (from Latin respectus) with the meaning of 'showing standards of behavior, appearance, etc. that are socially acceptable', most often associated with the upper classes of society, in this context can be understood as 'enough in amount or quality' (infml.). Thus the adjective serves to emphasize good manners in upper class society (the word respectable is frequent in descriptions and speech portrayals of the classes in question), and at the same time to express the narrator's subtle irony, which is in Henryk's anxiety and fear to annoy and tire Mrs. Rennick of his presence and in trespassing the etiquette and appropriateness accepted in upper class culture. 
The following episode is taken from the novel A Prisoner of Birth:

(2) "My friends and I were celebrating Gerald's thirtieth birthday-

"Gerald?" interrupted Pearson.

"Gerald Payne," said Craig. "He's an old friend from my days at Cambridge.

We were spending a convivial evening together, enjoying a bottle of wine."

Alex Redmayne made a note - he needed to know how many bottles.

Danny wanted to ask what the word "convivial" meant.

"But sadly it didn't end up being a convivial evening," prompted Pearson (Archer 2008: 18).

Before the judge is Craig, a graduate from Cambridge, and Danny who became a victim of perjury; unfairly accused of instigating a fight, he was sent to prison. $\mathrm{He}$ had no university education and did not understand the language the assaulter spoke. Just one word convivial (from Latin convivialis, from convivium 'a feast' (LEXICO)) was enough to draw a social demarcation line between the two without giving comments or any explanations. In this connection Simon Heffer's book Strictly English (Heffer 2010: 150-162) comes to mind, in which the author raises the question of inappropriate use of words of foreign origin, and of their misuse even by educated journalists. The reason lies in education, asserts S. Heffer, in insufficient (or even lack of) knowledge of French, Latin and Greek, which are properly studied only at Oxbridge. The knowledge of the languages with absolutely different grammar and lexical systems allows one to memorize and use words correctly and appropriately. It explains why these days dictionaries register loan words in wrong meanings - as the result of their misuse in society. Heffer writes, "It is an interesting policy for lexicographers to accept a word into a language with a new meaning purely because people confuse it with a word that begins with the same letter, has the same number of syllables, ends with the same suffix and generally sounds similar" (Heffer 2010: 139). It only proves that words of foreign origin are socially charged and cause problems for insufficiently educated speakers to use them accurately in speech and writing.

Socially marked is the adjective "histrionic" in the following example:

(3) James had never mentioned to anyone since leaving Oxford the class of degree he managed to secure, but for better or worse the fourth-class Honours degree was later abolished. After Oxford he joined the Grenadier Guards, which gave him considerable scope for his histrionic talents. This was indeed to be James's introduction to society life in London, and he succeeded as well as a personable, rich young viscount might be expected to do in the circumstances (Archer 2004: 51).

The adjective "histrionic" is registered as a formal word possessing a derogatory connotation (Longman Dictionary of English Language and Culture (1992)), and as archaic in ABBYY online dictionary. It came from Latin histrio (n-) 'actor' and, when used in the novel in conjunction with words of Latin origin: "managed", "secure" (from Latin secures), "abolish" (from Old French aboliss, from Latin abolere 'destroy'), and "society", French words "grenadier" and 
"guards" (French garde), a word "scope", Greek by origin, and others, renders the atmosphere at Oxford and the languages they are taught, though one cannot but feel slight irony on the part of the narrator.

In the novel $A$ Prisoner of Birth there is an episode when two characters Nick, of noble birth, and Danny, from socially unprivileged classes, have the following conversation:

(4) 'Looking forward.'

'Looking forward,' repeated Danny as they reached the entrance to the chapel, where they waited in line as each prisoner was given a body search before being allowed to enter.

'Why bother to search us before we go in?' asked Danny.

'Because it's one of the few occasions when prisoners from all four blocks can congregate in one place, and have a chance to exchange drugs or information.'

\section{'Congregate?'}

'Get together. A church has a congregation.'

'Spell it, ' demanded Danny (Archer 2008: 143).

It is another instance testifying to the socially indexical nature of words of foreign origin. The word 'congregate' came from Latin congregat - 'collected (into a flock), united', from the verb congregare, associated more with church congregations and religion. Now it is registered in dictionaries in the meaning 'to gather into a crowd or mass' (ABBYY) and in the novel it is juxtaposed with the verb 'to get together' of Germanic origin, more often than not used in informal speech, to highlight social differences of the characters, different level of education and upbringing. Only one verb serves the purpose.

Social implications of the words acquired historically have preserved their validity and relevance today and are extensively resorted to in order to indicate social or status differences between the interlocutors. This is one of the powerful and implicit means of social characterization in fiction. Antoinette Renouf supports this point of view by highlighting "the need or desire to indicate membership of a social or educational elite" (Renouf 2004: 528) among three reasons due to which French loan words are assimilated into the English language.

\section{c) CLASS 3}

The next class of foreign words is made up of the units that enter the upperclass vocabulary and are socially marked by definition. Aspiring for elegance, sophistication, beauty, perfection, etc. regarded as the ideal of nobility, the privileged classes assimilated a lot of words and nouns which translate the qualities and characteristics of upper-class representatives and therefore serve as social and cultural "signs", or indices, in fiction. Here belongs the adjective 'elegant' (from French or from Latin elegant-, elegans, related to eligere 'choose, select') (LEXICO). In our previous papers, this adjective was marked as part of the upperclass vocabulary (Ivushkina 2012). 
(5) On the stroke of 7.30 P.M. on the appointed Thursday Jean-Pierre arrived. Stephen admired the elegant dinner jacket and large floppy bow tie that his guest wore, while he fingered his own little clip-on, surprised that Jean-Pierre Lamanns, who had such obvious savoir faire, could also have fallen victim to Prospecta Oil (Archer 2004: 83).

In the adduced example, not only does the adjective elegant serve as a social sign of Jean-Pierre Lamanns' background, but the description of his appearance on the whole - 'the elegant dinner jacket and a bow tie' - is socially marked (Ivushkina 2017). The social implication is reinforced by French "savoir faire" denoting 'to act or speak appropriately in social situation'.

In the following excerpt, the combination of words "formal atmosphere and decorum" as well as "sophistication", also serves as social indices of the elite, as they reflect the basic principles on which upper class culture rests. Three of them are of Latin origin - formalis, decorus, and sophisticatus, and the word atmosphere has Greek roots: atmos + sphaira.

(6) Harvey had enjoyed Vegas when he was younger, but the older he became the more he appreciated the sophistication of the French. He had grown to prefer the formal atmosphere and decorum of this particular Casino (Archer 2004: 187).

The word debonair (from Old French debonaire 'of good disposition') with the stylistic marker 'appreciative', and 'becoming rare' found in Longman Dictionary of English Language and Culture (LDELC: 329) and having no stylistic markers in the contemporary Oxford online dictionary includes into its semantic field all the qualities inculcated in a young upper class person: suave, sophisticated, civilized and well-mannered, courteous, gallant, chivalrous, refined, polished, genteel, courtly, etc., and is therefore socially marked. The French language and culture introduced the concept of civility and manners, courtesy and gallantry, and all the above-mentioned adjectives, French or Latin by origin, are socially marked and translate social standing of the personages in speech and fiction.

(7) On Monday morning, James drove Anne back to London and changed into the most debonair of his suits (Archer 2004: 211).

It is possible to adduce a long list of loan words included into the sphere of upper class life in its various manifestations reflecting their pastime, hobbies, social events and sports. Among them are the following words selected from the novels under investigation: astute (from obsolete French astut, from Latin astutus 'craft'), preposterous (from Latin praeposterus 'reversed, absurd'), impeccable (from Latin impeccabilis 'not + sin') (manners, appearance), loquacious (from Latin loquax, loquac- 'talk'), authoritative (from French autorite, from Latin auctoritas, from auctor 'originator, promoter'), excellent (from French excellent 'being preimenent', from Latin excellere) etc. (LEXICO).

(8) James was beginning to feel ill, and it certainly was not the excellent salmon sandwiches that were causing his discomfort (Archer 2004: 107). 
The adduced example conveys the narrator's irony by using the socially marked adjective "excellent" and the noun "discomfort" (from "comfort") in their enantiosemiotic meanings. This class of words is considered separately.

\section{d) CLASS 4}

Class 4 includes words of foreign origin used in an ironic or humorous way by the narrator and revealed in different contexts; to share the author's irony, one is supposed to have a good knowledge and feeling of language, it requires sharing the code of the in-group members, otherwise, ironic or humorous connotations of the word are lost upon the reader.

Let us adduce some examples:

(9) Terry Robards turned out to be a wiry American wearing a perpetual smile. Terry immediately made Stephen feel at ease, a knack he had developed almost subconsciously over the years and which was a great asset when digging a little deeper for stories (Archer 2004: 75-76).

The adjective "perpetual" (from French perpetual, from Latin perpetualis 'continuing throughout') (LEXICO) is used in this context ironically to emphasize a typically 'demonstrative' 'American smile', which does not at all reflect the real feeling a person is experiencing. The verb "wearing" only creates the image of a 'special dress' always ready to be worn on necessary occasions. The adjective "perpetual" usually employed in connection with a position, job, or trophy held for life, to denote an uninterrupted and endless feelings or blooming of flowers, creates a metaphoric and exaggerated description of an American smile, which helps convey the ironic attitude of the narrator and the stereotypical attitude of the British people towards Americans at large.

The following sentence also reveals an ironic attitude of the narrator in the phrase "excellent sandwiches":

(10) The others attached page $38 A$ to their dossiers, aware once again how much detailed research Stephen had undertaken. James was beginning to feel ill, and it was not the excellent salmon sandwiches that were causing his discomfort (Archer 2004: 107).

The plan the characters were brooding over and preparing for in order to return the stolen money and take revenge on the fraudster for becoming victims occupied Stephen's mind and body. James, helpless and sheepish, felt absolutely at a loss and depressed. He "was beginning to feel ill" translates the inner state of the character. "...it was not the excellent salmon sandwiches that were causing his discomfort" creates a clash between his physical and mental state, discomfort of mind and body which only conveys and highlights the narrator's ironic attitude to the situation in which all the characters found themselves.

In the excerpt below, appealing is the use of the word "ministrations" (from Latin ministrare 'wait upon', meaning the 'provision of assistance or care'), which is obviously used humorously in the situation artificially created by the characters. 
The plot of the novel is funny in itself; the tone of the novel is alike, it is also felt in a humorous attitude of the narrator unveiled in different episodes of the novel Not a Penny More, Not a Penny Less.

(11) James nodded and set off at the funeral pace.

"Nurse Faubert."

"Yes, Doctor Barker." Her hands were tucked primly under her blue cape, and her French accent was enchanting. Robin thought Harvey would not find her ministrations unwelcome.

"My patient has just had an operation for the removal of a gallstone and will need plenty of rest" (Archer 2004: 198).

It is noteworthy that the noun "ministrations" is registered in Longman Dictionary of English Language and Culture (LDELC 1992: 628) with a stylistic marker 'formal' but in ABBYY it is registered as 'formal' or 'humorous'. The use of formal words foreign by their origin is always like walking on a minefield, because, though assimilated, they retain their official coloring and 'alien' nature, thus making contrast to or even disagreeing with the context in which they are used. That is why they should be used with caution. Though there is no British counterpart in the novel, it could be replaced by 'dramatic' or 'theatrical' (Greek and Latin correspondingly), the adjectives with which everybody is well familiar.

One of the powerful means of social characterization is the incompatibility of the style and the subject matter created by the contrast of registers:

(12) Would the heavens descend if he told the dreaded Mrs. Page-Stanley that she was a malodourous old woman in need of nothing more medically taxing than a new set of dentures? And would he be struck off if he personally administered to the nubile Miss Lydia de Villiers a good dose of what she so clearly indicated she desired? (Archer 2004: 39).

One cannot but feel the narrator's irony in the words "nubile" (from Latin nubilis 'marriageable', from nubere 'cover or veil oneself for a bridegroom') and "personally administered" (Old French, from Latin administrare), and in the word "odour" (from Latin odor, 'smell, scent') (LEXICO) which is never touched upon in a conversation or if it is then only euphemistically, which creates dissonance between lofty and elevated words and the topic usually closed for discussion.

\section{Conclusion}

The analysis of two novels by Jeffrey Archer Not a Penny More, Not a Penny Less and A Prisoner of Birth from a sociolinguistic and functional points of view has shown that a literary layer of the English vocabulary deserves the attention of a researcher. Coming from different languages, literary words of foreign origin are difficult to use and memorize as they reflect languages with different lexical and grammar systems and, therefore, in order to use such words appropriately, one must be highly educated and knowledgeable. Education has always been a privilege in British society, the first most prestigious universities were founded for the elite, that 
is what the ruling classes of Great Britain incorporated into their culture in order to cultivate their own sociolect, allowing them to stand out from the rest.

The cultivation of the upper class sociolect has been reared for centuries and it has also been rooted in literature (world literature including). Literature has always been a starter for conversation and communication in society and in-group members have always been expected to share impressions of the books in fashion and even cite passages and different pieces from prose and poetry, which created an upper class jargon for those who belong and share it. It is the most 'challenging' stratum of the English vocabulary, not easy to assimilate or acquire, and this explains why it has remained a solid part of upper class culture.

The study of literary words of foreign origin has shown that this stratum of words is heterogeneous and there is a lot of controversy in classifications of the words. In fiction under analysis, they function as terms, as words with social implications acquired in the course of social history development, as words with their Germanic counterparts serving for contrasting the speakers' social positions and for creating humorous or ironic attitudes of the character or the narrator. Such words are often accompanied and intensified by French words and phrases enhancing their social implications.

If the words of Class 1, which are terms, are precise in their meanings and serve to denote different notions, inventions and innovations in different spheres of our life, the three other classes require knowledge on the part of the reader to grasp the social constituent of the meaning. The study and description of the upper class language and culture helps to comprehend the social indexicality of this category of words.

(C) Tatiana Ivushkina, 2020 (c)creative

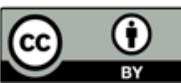

This work is licensed under a Creative Commons Attribution 4.0 International License https://creativecommons.org/licenses/by/4.0/

\section{REFERENCES}

Ahmanova, Olga S. 2009. Ocherki po obschej i russkoj leksikologii [Essays on General and Russian Lexicology], Moscow: LIBROKOM, 296.

Aitchinson, Jean. 1987. The English Language and Images of Matter (Language and Language Learning), London: Oxford University Press.

Algeo, John. 1980. "Where Do All the New Words Come from?", American Speech 55, 264-277.

Antrushina, Galina B. 2006. Leksikologiya anglijskogo yazyka [Lexicology of the English Language]. Moscow: Drofa.

Arnold, Irina V. 2016. Stilistika. Sovremenny anglijskij yazyk: uchebnik dlya vuzov/I.V. Arnold [Stylistics. Contemporary English: a textbook for University students], 13 ed., Moscow: Flinta, 384. 
Carter, Ronald, Nash, Walter. 1983. Language and Literariness, Prose Studies 6 (2). 124-41. DOI: http://doi.org/10.1080/01440358308586190.

Carter, Ronald; Nash, Walter. 1991. Seeing Through Language, Wiley-Blackwell, 280.

Cook, Guy. 1994. Discourse and Literature: The Interplay of Form and Mind. Oxford: Oxford University Press. 285. DOI: https://doi.org/10.1177/096394709600500108.

Craig, Collette G. (eds.). 1986. Noun Classes and Categorization. Proceedings of a Symposium on Categorization and Noun Classification, John Benjamin Publishing Company, 481. DOI: https://doi.org/10.1075/tsl.7.

Crystal, David. 2010. The Cambridge Encyclopedia of Language, Cambridge University Press. 515.

Fowler, Roger (eds.). 1966. Essays on Style and Language. London: Routledge \& Kegan Paul. Gak, Vladimir G. 1977. Sopostavitelnaya leksikologiya. Na materiale francuzskogo i russkogo yazykov. [Comparative lexicology: On the material of French and Russian], Moscow: Mezhdunarodnye otnosheniya. 264.

Galperin, Iljya R. 2012. Ocherki po stilistike anglijskogo yazyka: Opyt sistematizacii vyrazitelnyh sredstv [Essays on stylistics of the English Language: experimental systematization of expressive means], Moscow: LIBROKOM, 376.

Heffer, Simon. 2010. Strictly English. Random House Books. 322.

Ivushkina, Tatiana A. 2012. Sociolingvisticheskij aspekt prilagatelnogo v anglijskoi rechi [Sociolinguistic aspect of the adjective in English speech]. Philology at MGIMO 47 (62). $58-70$.

Ivushkina, Tatiana. 2017. Words as indices of social and cultural identity. Literature, Language and Linguistics 3 (3). 96-102. DOI: 10.18178/ijlll.2017.3.3.117.

Kostomarov, Vitalij G. 1965. O razgranichenii terminov «ustnyj» $i$ «razgovornyj», «pismennyj» $i$ «knizhnyj» [On differentiation of the terms «oral» and «colloquial», «written» and «bookish»], Problemy sovremennoj filologii. Moscow, 172-177.

Kuznec, Marianna D. \& Yurij M. Skrebnev. 1960. Stilistika anglijskogo yazyka. Posobie dlya studentov pedagogicheskih vuzov [Stylistics of the English Language. Textbook for students of pedagogical universities], Leningrad: Uchpedgiz.

Morohovskij, Aleksandr N. 1991. Stilistika anglijskogo yazyka: uchebnik/ A.N. Morohovskij, O.P. Vorobyova, N.I. Lihosherst, et al. [Stylistics of the English Language: a textbook]. Kiev: Vysshaya shkola, 272.

Quirk, Randolph. 1972a. The English Language and Images of Matter (Language and Language Learning 34), London: Oxford University Press. 136.

Quirk, Randolph. 1972b. Words at Work: Lectures on Textual Structures. Harlow: Longman.

Rakushina, Alfiya K. 2019. Semanticheskie izmeneniya vanglijskoi literaturno-knizhnoj leksike (diahronicheskij aspect) [Semantic changes in English literary words (diachronic aspect)]. Philology at MGIMO 18 (2) 19-26. DOI: 10.24833/2410-2423-2019-2-18-19-26.

Rakushina, Alfiya K. \& Tatiana A. Ivushkina. 2018. «Leteraturno-knizhnaya leksika» v lingvisticheskoj literature [Literary-bookish words as elucidated in linguistic literature]. Philology and Culture 2 (52). 111-124. Kazan.

Renouf, Antoinette. 2004. Shall We Hors D'Oeuvre's?: The Assimilation of Gallicism into English In Laporte, Eric, Christian Leciere, Mirelle Piot \& Max Silberztein (eds.), Syntaxe, Lexique et Lexique-Grammaire: Hommage a Maurice Gross, Lingvisticae Investigationes Supplements 24. 527-545. John Benjamin. Amsterdam/Philadelphia.

Skrebnev, Yurij M. 2003. Osnovy stilistiki anglijskogo yazyka. Uchebnik. 2-e izd. [Fundamentals of the English Stylistics], 224. Moscow: Astrel-AST.

Yarzeva, Viktoriya N. 2004. Razvitie nacionalnogo literaturnogo anglijskogo yazyka [Development of the national literary English language]. Moscow, 285. 


\section{Dictionaries}

ABBYY On-line Dictionary. [Electronic resource]. URL: http://www.abbyyonline.com (accessed on October 10, 2019)

Contemporary Oxford online dictionary - LEXICO (powered by Oxford) [Electronic resource].

URL: http://www.lexico.com (accessed on October 10, 2019)

Longman Dictionary of English Language and Culture, Longman, 1992.

\section{Books}

Archer, Jeffrey. 2004. Not a Penny More, Not a Penny Less. St. Martin's Paperbacks. 305.

Archer, Jeffrey. 2008. A Prisoner of Birth, Pan Books. 616.

Article history:

Received: 30 May 2020

Revised: 15 September 2020

Accepted: 17 September 2020

\section{История статьи:}

Дата поступления в редакцию: 30 мая 2020

Дата принятия к печати: 17 сентября 2020

\section{Bionote:}

Tatiana A. IVUSHKINA is Head of English Department №3 at MGIMO University, Faculty of International Journalism. She is deputy editor-in-chief of the journal Philology at MGIMO. Most of her publications reflect her scholarly interest in the study of the upper classes language and culture.

\section{Contact information:}

MGIMO University

76 Vernadskogo, Moscow, 119454, Russia

e-mail: Tatiana.ivushkina@gmail.com

ORCID ID: 0000-0003-3024-9520

\section{Сведения об авторе:}

Татьяна Александровна ИВУШКИНА - доктор филологических наук, профессор, заведующий кафедрой английского языка № 3 факультета международной журналистики МГИМО. Ответственный секретарь, зам. главного редактора журнала «Филологические науки в МГИМО». Ее многочисленные публикации посвящены научной теме иследования «Язык и культура высших классов общества».

\section{Контактная информация:}

МГИМО

России, Москва, 119454, пр. Вернадского, 76

e-mail: Tatiana.Ivushkina@gmail.com

ORCID ID: 0000-0003-3024-9520 